\title{
INAA to Determine Trace Element Concentrations in the Hair of Street Children of Isfahan City, Iran
}

\author{
Khadijeh Rezaee Ebrahim Saraee $^{1 *}$, Mohammad Reza Abdi ${ }^{2}$, Mohammad Mehdi Gharipour ${ }^{3}$, \\ Nayereh Soltani ${ }^{4}$ \\ ${ }^{1}$ Department of Nuclear Engineering, Faculty of Advance Sciences and Technologies, University of Isfahan, Isfahan, Iran \\ ${ }^{2}$ Department of Physics, Faculty of Science, University of Isfahan, Isfahan, Iran \\ ${ }^{3}$ Safahan Institute of Higher Education, Isfahan, Iran \\ ${ }^{4}$ Departments of Physics, Universiti Putra Malaysia, UPM Serdang, Selangor, Malaysia \\ Email: "kh.rezaee@ast.ui.ac.ir
}

Received April 13, 2013; revised June 16, 2013; accepted July 19, 2013

Copyright (C) 2013 Khadijeh Rezaee Ebrahim Saraee et al. This is an open access article distributed under the Creative Commons Attribution License, which permits unrestricted use, distribution, and reproduction in any medium, provided the original work is properly cited.

\begin{abstract}
This study aimed to assess trace element concentrations in the hair of street children. Nutritional status was assessed by 24 hours' dietary recall and anthropometric measurements. Data analysis found that $\mathrm{Br}, \mathrm{Sc}, \mathrm{Sm}$ and Ti concentrations show a normal distribution, and there is no significant difference between street children and control group. However, in the street children's hair, the levels of $\mathrm{Au}, \mathrm{U}, \mathrm{V}$ are decreased and the levels of $\mathrm{Co}, \mathrm{La}, \mathrm{Sb}$, Th are increased compared to the control group.
\end{abstract}

Keywords: Hair; INAA; Isfahan; Street Children; Trace Elements

\section{Introduction}

Approximately ten million children around the world are homeless and 150 million spend much of their time on the streets [1]. Living in street, exposure to the smoke of cars and lack of family and social supports can remarkably affect the health of these children and the society $[2$, 3]. So far, almost all reports in Iran come from subjects of drugs, poverty, sexual and physical abuse and little information on body health is available, then in this research we focus on this matter.

However, although there are studies which focus on the health status of street children in a specific area of the world $[4,5]$, to date, few studies actually investigate the trace element nutrition status of the street children. In fact, trace elements, as well as vitamins and minerals, play an important role in maintaining metabolic homeostasis in the future of them so it is needed to study the trace elements in order to prevent of many age-associated diseases [6].

The study advantages of biomonitoring of trace elements and organic pollutants using body tissues to investigate health and nutritional status of human have been proved [6-13]. Determination of trace element concentra-

${ }^{*}$ Corresponding author. tions and their distribution in body tissues also can be a tool to assess the health status of them [6,14-19].

Unfortunately, up to now, no data for trace element concentrations in the hair of street children are available in the published literature. Within the context of the perspectives mentioned above, the aim of our study was to investigate trace element concentrations in the hair of healthy street children in Isfahan city, which is an industrial and big city in Iran, for providing a data base. So far, awareness especially concerns people living close to industrial sites or in geological areas characterized by anomalous enrichments in metal and metalloids, and also in urban areas affected by traffic-derived air pollution [20]. For this reason, the concentration of heavy metals is also studied on the street children of this area [21]. Simultaneously, body composition tests and 24 hours' dietary recall and anthropometric measurements and the relation between these parameters and trace element were studied.

\section{Material and Methods}

The 17 children ( 5 boys and 12 girls), aged 6 - 15 are selected from the Isfahan city, which is a industrial region and has traffic contamination as it has just 25 clean days last year. Consent of the orphanage mentors was required 
for study participation. Interviews with their or phanage mentors indicated that all of the children were left in their houses and lived in the streets and none of them were receiving special education or related services for health issues. Also, 3 children ( 1 boy and 2 girls), aged 8 - 12, living with their family, are selected. Not only the subjects and their orphanage mentors were interviewed via questionnaire in order to identify and control variables affecting health issues (as the food 24 recall forms) but body composition analysis also has been done. Samples were washed according to the procedure recommended by the IAEA and about $100 \mathrm{mg}$ samples were washed [22]. Seven biological standard reference materials, Peach Leaves NIST-1547, Bovine Liver NIST-1577b, Rice Flour NBS-1568a, Coal Fly Ash NIST 1633b, Pine Needles NIST-1575, Apple Leaves NIST-1515 and Trace Elements in Human Hair CRM-397 were chosen as quantity control SRM. Samples or standards were placed in a $5 \times 5 \mathrm{~cm}^{2}$ polyethylene film that had been cleaned with $\mathrm{C}_{2} \mathrm{H}_{5} \mathrm{OH}$ with $70^{\circ} \mathrm{C}$ temperature and deionized water.

The samples and standards were irradiated with thermal neutrons from a Miniature Neutron Source Reactor, Atomic Energy Organization of Iran. The irradiation, cooling and counting times for the first and second counting of radio activity measurements, and the determined isotopes for each cycle by comparative method are summarized in Table 1. Gamma ray spectra of the irradiated samples were obtained with a well type HPGE detector. This type of detectors was mainly used to minimize the geometry errors arising during gamma ray counting of the hair samples. The resolution of this detector was $2.0 \mathrm{keV}$ for the $1332 \mathrm{keV}$ peak of ${ }^{60} \mathrm{Co}$. The NAA software SPAN was used for the identification of the radionuclides and the calculation of their activities. The relative method was used to calculate element concentrations. The analytical results of the samples are in good agreement with the certified values.

Nutritional assessment was evaluated by measurement of height, weight and body mass index (BMI) calculation. Body weight was taken to the nearest $0.1 \mathrm{~kg}$. Subjects were asked to be in light clothing, barefoot, standing straight up and looking at the front without any movement at the centre of scale. To measure height, a portable stadiometer was used, with the subjects standing upright, barefoot, legs straight with their heels close together, back straight and arms stretched along the body in Frankfurt horizontal level position. BMI was defined as weight (in kilograms) divided by the square of the height (in meters). Respondents were categorized into five groups: severe thinness, thinness, normal weight, overweight and obese by cut-off points for BMI-for-age [23]. Food intake was assessed using a 24-hour dietary recall. Portion size of food items was estimated based on the household measurements. Then, all were converted to gram based
Table 1. Neutron activation analysis conditions for human hair.

\begin{tabular}{ccccc}
\hline $\begin{array}{c}\text { Neutron flux } \\
\times 10^{11} \mathrm{ncm}^{-2} \mathrm{~s}^{-1}\end{array}$ & $\begin{array}{c}\text { Irradiation } \\
\text { time }\end{array}$ & $\begin{array}{c}\text { Decay } \\
\text { time }\end{array}$ & $\begin{array}{c}\text { Counting } \\
\text { time }\end{array}$ & $\begin{array}{c}\text { Elements } \\
\text { determined }\end{array}$ \\
\hline 1 & $2 \mathrm{Min}$ & $80 \mathrm{Sec}$ & $500 \mathrm{Sec}$ & $\mathrm{Ti}, \mathrm{V}$ \\
5 & $7 \mathrm{Hour}$ & 4 Days & $1500 \mathrm{Sec}$ & $\mathrm{As}, \mathrm{Au}, \mathrm{Br}, \mathrm{Sm}, \mathrm{U}$, \\
5 & 7 Hour & 10 Days & $5000 \mathrm{Sec} \mathrm{Co}, \mathrm{Hf}, \mathrm{La}, \mathrm{Sb}, \mathrm{Sc}, \mathrm{Th}$ \\
\hline
\end{tabular}

on Iranian food composition table $[24,25]$ to inter in analysis software. Nutritionist IV software program version 3.5.2 was used since there was not any specific analysis software based on Iranian foods in order to analyze the energy and different macronutrients (carbohydrate, protein, fat) intake of the subjects. The energy requirement of patients was calculated using standard equation for each subject with activity factor 1.13 for boys and 1.16 for girls according to DRI [26]. The mean consumption of macronutrient was compared to DRI recommendation since there was no recommended nutrient intake available based on Iranian diet. All statistical analyses were done with the Statistical Package for the Social Sciences (SPSS), version 16.0. Data were utilized by descriptive statistics like mean and percentage. The mean and standard deviation were used to summarize some variables.

\section{Result and Discussion}

The most abundant chemical elements found (Table 2) were $\mathrm{Br}$ and $\mathrm{Ti}(\mathrm{Ti}>\mathrm{Br})$, with concentrations average $\mathrm{Br}$ $=1.42 \mu \mathrm{g} / \mathrm{g}$ and $\mathrm{Ti}=4.65 \mu \mathrm{g} / \mathrm{g}$. Other elements with concentrations greater than $1 \mu \mathrm{g} / \mathrm{g}$ were, in order of abundance, $\mathrm{V}>\mathrm{La}>\mathrm{Sb}>\mathrm{Co}>\mathrm{U}>\mathrm{Hf}>\mathrm{Th}>\mathrm{Au}(=\mathrm{Sc})>$ $\mathrm{Sm}$. Also observed was the great variability of many elements, as shown by the coefficients of variation (CV) ranging from $31.9 \%(\mathrm{Sc})$ to $184.1 \%(\mathrm{Au})$. The calculated $\mathrm{CVs}$ reflect the intrinsic biological variability within the group of street children, together with variations due to lifestyle, and small-scale environmental factors [15]. Regression analysis did not reveal any highly significant relationship between variables. For example, just two elements $\mathrm{Co}-\mathrm{Sc}$ and $\mathrm{La}-\mathrm{Sc}$ have $\mathrm{R}$-squared values greater than 0.6. Because $\mathrm{Br}$ is an essential element in our body, high concentration of $\mathrm{Br}$ in the hair samples is not related to the environmental effects [27]. The second abundance among trace elements is Ti. Hair is extremely susceptible to contamination with titanium from hair treatment products. However, titanium concentrations of individual human foods have not been reported.

The high concentration of As in street children compared to control group (in Figure 1) may be related to the use of contaminated water $[28,29]$ or the smoking status during their lifestyle [30]. However, the average concen- 
Table 2. Raw data for street children group with individual concentration in $\mathbf{n g} / \mathrm{g}$ for detected trace elements.

\begin{tabular}{|c|c|c|c|c|c|c|c|c|c|c|c|c|c|}
\hline Sample & As & $\mathrm{Au}$ & $\mathrm{Br}$ & $\mathrm{Co}$ & $\mathrm{Hf}$ & $\mathrm{La}$ & $\mathrm{Sb}$ & $\mathrm{Sc}$ & $\mathrm{Sm}$ & Th & $\mathrm{Ti}$ & $\mathrm{U}$ & $\mathrm{V}$ \\
\hline 1 & 0 & 10 & 1230 & 110 & 110 & 180 & 100 & 20 & 18 & 39 & 7250 & 95 & 170 \\
\hline 2 & 50 & 10 & 1010 & 73 & 30 & 470 & 29 & 22 & 19 & 29 & 7780 & 126 & 140 \\
\hline 3 & 0 & 12 & 1220 & 150 & 51 & 120 & 139 & 18 & 10 & 24 & 8170 & 0 & 400 \\
\hline 4 & 480 & 7 & 1130 & 36 & 43 & 119 & 149 & 11 & 11 & 33 & 7930 & 71 & 130 \\
\hline 5 & 0 & 4 & 800 & 42 & 30 & 100 & 28 & 10 & 9.4 & 24 & 5630 & 40 & 210 \\
\hline 6 & 47 & 5 & 980 & 0 & 48 & 124 & 45 & 13 & 9.4 & 23 & 0 & 51 & 180 \\
\hline 7 & 30 & 8 & 990 & 33 & 23 & 74 & 22 & 11 & 10 & 0 & 4080 & 47 & 230 \\
\hline 8 & 0 & 3 & 860 & 29 & 47 & 72 & 30 & 8.7 & 16 & 17 & 5520 & 150 & 160 \\
\hline 9 & 47 & 6 & 470 & 49 & 0 & 123 & 57 & 12 & 7.1 & 0 & 5810 & 0 & 260 \\
\hline 10 & 0 & 5 & 1010 & 24 & 0 & 73 & 26 & 10 & 0 & 44 & 0 & 42 & 150 \\
\hline 11 & 0 & 20 & 820 & 29 & 39 & 83 & 35 & 11 & 5.6 & 26 & 0 & 0 & 240 \\
\hline 12 & 77 & 100 & 840 & 39 & 0 & 76 & 40 & 12 & 7.9 & 23 & 5880 & 0 & 160 \\
\hline 13 & 24 & 4 & 1990 & 0 & 25 & 94 & 14 & 8.8 & 0 & 0 & 6970 & 0 & 120 \\
\hline 14 & 0 & 3 & 1370 & 0 & 43 & 62 & 20 & 12 & 5.8 & 0 & 5000 & 0 & 170 \\
\hline 15 & 61 & 5 & 4090 & 86 & 42 & 88 & 34 & 14 & 0 & 29 & 0 & 0 & 210 \\
\hline 16 & 62 & 7 & 3430 & 0 & 0 & 93 & 35 & 9.3 & 0 & 25 & 0 & 0 & 120 \\
\hline 17 & 38 & 3 & 1950 & 34 & 30 & 95 & 22 & 8.7 & 0 & 0 & 8270 & 0 & 110 \\
\hline Min & 0 & 3 & 470 & 0 & 0 & 62 & 14 & 8.7 & 0 & 0 & 0 & 0 & 110 \\
\hline Max & 480 & 100 & 4090 & 150 & 110 & 470 & 149 & 22 & 19 & 44 & 8270 & 150 & 400 \\
\hline Average & 53.9 & 12.5 & 1422.9 & 43.2 & 33 & 120.3 & 48.5 & 12.4 & 7.6 & 19.8 & 4605.2 & 36.6 & 185.9 \\
\hline $\mathrm{CV}$ & 209.7 & 183.6 & 67.9 & 95.3 & 81.4 & 78.5 & 84.3 & 32 & 82.9 & 73.5 & 71 & 132.9 & 38.1 \\
\hline \multicolumn{14}{|c|}{ Control group } \\
\hline 18 & 0 & 50 & 1260 & 38 & 55 & 81 & 75 & 9.8 & 0 & 0 & 9250 & 0 & 320 \\
\hline 19 & 0 & 9 & 1090 & 27 & 38 & 83 & 13 & 11 & 0 & 0 & 0 & 130 & 200 \\
\hline 20 & 39 & 8 & 760 & 0 & 23 & 78 & 17 & 7.8 & 11 & 25 & 5500 & 78 & 110 \\
\hline Average & 13 & 22.3 & 1036.7 & 21.7 & 38.7 & 80.7 & 35 & 9.5 & 3.7 & 8.3 & 4916.7 & 96.3 & 210 \\
\hline
\end{tabular}

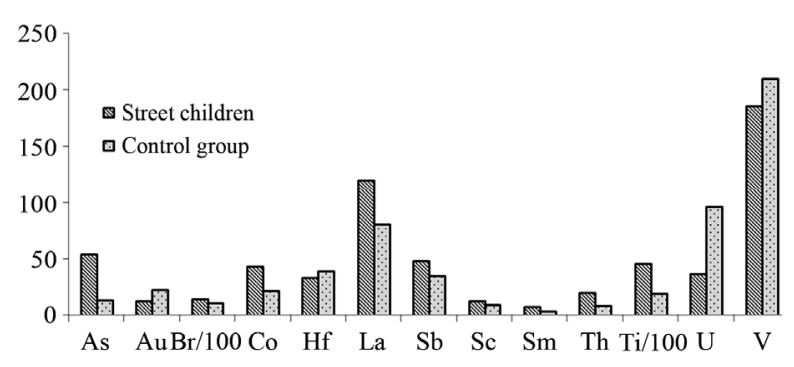

Figure 1. Comparison of mean concentration of trace elements between street children and control group.

tration of As in the hair of street children in Isfahan is less than those in China, Gambodia, India, Italy, Nigeria and Malaysia [31-33] and is same compared to Japan and is greater than those in Canada, USA and Poland [32].

Vanadium content between control groups is greater compared to street children. Vanadium is commonly found in vegetables and seafood. Although for non-occupationally exposed individuals, the primary sources of these metals are food, drinking water and breathed air, according to their usual concentration sin ambient air, the most probable exposure pathways remain foodstuffs and water [20]. The content of cobalt in the street children is greater than control groups. Cobalt hair levels occasionally reflect external contamination from hair preparation products. Occupational or environmental exposures to cobalt dusts or chemicals may cause exogenous contamination. The mean concentration of La in street children was $120.3 \pm 90.0 \mathrm{ng} / \mathrm{g}$ greater than that reported in the literature $(11.0 \pm 1.00 \mathrm{ng} / \mathrm{g})[34]$.

Lanthanum is dumped in many different ways to the environment, mainly by petrol-producing industries. It may enter the environment when household equipment is thrown away. Then it accumulates in soils and water 
soils and eventually leads to increasing concentrations in humans, animals and soil particles. The concentrations of uranium in both street children and control groups are compared with those in the literatures $[35,36]$. The results show the concern of uranium for individual child is less than that maximum reported $(180.0 \mathrm{ng} / \mathrm{g}$ and 170.0 $\mathrm{ng} / \mathrm{g}$ respectively).

The summary of anthropometric data was shown in Table 3. The mean of anthropometric parameters for male subjects were $27 \pm 6.9 \mathrm{~kg}$ (weight), $14.9 \pm 1.3$ $\mathrm{kg} / \mathrm{m}^{2}$ (BMI), and $133.8 \pm 13.3 \mathrm{~cm}$ (height). Female subjects had higher mean of weight $(38.2 \pm 13.7 \mathrm{~kg})$, BMI $\left(18.5 \pm 4.9 \mathrm{~kg} / \mathrm{m}^{2}\right)$, height $(142.7 \pm 11.1 \mathrm{~cm})$. Distribution of weight-for-height among subjects showed that $17.6 \%$ of all subjects were wasted $\left(<3^{\text {rd }}\right.$ percentile) and $10.0 \%$ of all subjects were stunted $\left(<3^{\text {rd }}\right.$ percentile). Obesity was seen only among $5.9 \%$ of subjects. According to weight-for-age relative to the WHO reference standard, $11.8 \%$ were underweight $\left(<3^{\text {rd }}\right.$ percentile). Mean energy and macronutrients intake according to one-day food recall of male and female subjects were showed in Table 3. The mean intakes of energy and protein of male and female subjects were $1682 \pm 129 \mathrm{kcal} /$ day and $65.9 \pm 8.4$ $\mathrm{g} /$ day and $1484 \pm 398 \mathrm{kcal} /$ day and $38.7 \pm 12.3 \mathrm{~g} /$ day, respectively. Comparison of the mean percentage intake of energy and protein of subjects with recommended of energy and protein according to reference values was done. Percentage achievements of energy for male and female subjects were $99.4 \%$ and $99.8 \%$, meaning that subjects almost achieved their energy needs based on estimated energy requirement (EER). Protein intake of subjects achieved $100 \%$ of their protein needs based on DRI recommendation in both males $(188.2 \%)$ and females (117.2\%).

In this study, protein and energy intakes in both gender all most achieved reference value. The results were compared to the nutritional status and dietary adequacy of single homeless women and their children in Shelters [37] and the results were consistent. Moreover, our results were compared to the obtained results in Pakistan and Indonesia. The obtained results showed that $17.6 \%$ of street children were wasted and $10 \%$ were stunted while in Pakistan 12\% were wasted and $20 \%$ were stunted, in Indonesia, $7 \%$ were wasted and $52 \%$ were stunted $[4,38]$.

\section{Conclusion}

This study determined trace element concentrations in the hair of street children for the first time. Thirteen trace elements (As, Au, Br, Co, Hf, La, Sb, Sc, Sm, Th, Ti, U and $\mathrm{V}$ ) in the hair of 17 healthy street children living in Isfahan, Iran were determined by neutron activation analysis method. The average values of these trace elements together with their respective ranges and coefficient variation values were presented and relevant comments
Table 3. The mean of anthropometric and food intake of street children.

\begin{tabular}{lcccc}
\hline & \multicolumn{2}{c}{ Male } & \multicolumn{2}{c}{ Female } \\
\cline { 2 - 5 } & Mean + SD & Range & Mean + SD & Range \\
\hline Weight $(\mathrm{kg})$ & $27 \pm 6.9$ & $17.5-36.5$ & $38.2 \pm 13.7$ & $22.7-74.3$ \\
Height $(\mathrm{cm})$ & $133.8 \pm 13.3$ & $112.0-147.0$ & $142.7 \pm 11.1$ & $120.0-156.5$ \\
BMI (kg/m²) & $14.9 \pm 1.3$ & $13.3-16.9$ & $18.5 \pm 4.9$ & $12.3-31.7$ \\
Energy (kcal) & $1682 \pm 129$ & $1555-1880$ & $1484 \pm 398$ & $833-2366$ \\
Protein (g/day) & $65.9 \pm 8.4$ & $51.3-71.6$ & $38.7 \pm 12.3$ & $23.3-70.4$ \\
\hline
\end{tabular}

on them were made. Bearing in mind that the street children spend most of their time in the street, they are influenced mostly by environmental situation. We hypothesized that these baseline data obtained from the healthy street children could be reliably used as monitors leading to better assessment of the health status in this social group.

\section{Acknowledgements}

The Authors thank the research fellows of the Laboratory of Activation Analysis, Isfahan Research and, Fuel Production Center, for their technical advice and State Welfare Organization in Isfahan city. We are also deeply grateful to engineer Farshad Majidi who actively took part in all stages of this work.

\section{REFERENCES}

[1] P. Vahdani, M. S. M. M. Hosseini, L. Gachkar and K. Sharafi, "Prevalence of Hepatitis B, Hepatitis, Human Immunodeficiency Virus, and Syphilis among Street Children Residing in Southern Tehran, Iran," Archives of Iranian Medicine, Vol. 9, No. 2, 2006, pp. 153-155.

[2] F. Habib, R. Nayaib, K. Khan, A. Jamal, A. A. Cheema and N. Imam, "Occupational Health Hazards among Street Children," Biomedica, Vol. 23, No. A, 2007, pp. 92-95.

[3] J. L. P. Lugalla and J. K. Mbwambo, "Street Children and Street Life in Urban Tanzania. The Culture of Surviving and Its Implications for Children's Health," Joint Editor and Blakwell Publisher Ltd., Oxford, 1999.

[4] A. Moazzam, S. Shahab, H. Ushijima and A. D. Muynck, "Street Children in Pakistan: A Situational Analysis of Social Conditions and Nutritional Status," Social Science \& Medicine, Vol. 59, No. 8, 2004, pp. 1707-1717. http://dx.doi.org/10.1016/j.socscimed.2004.01.031

[5] M. Kudrati, M. L. Plummer, N. Dafaalla and E. H. Yousif, "Children of the sug: A Study of the Daily Lives of Street Children in Khartoum, Sudan, with Intervention Recommendations. Child Abuse \& Neglect, Vol. 32, No. 4, 2008, pp. 439-448.

http://dx.doi.org/10.1016/j.chiabu.2007.07.009

[6] Y. Li, L. Yang, W. Wang, H. Li, M. J. Lv and X. Zou, "Trace Element Concentrations in Hair of Healthy Chi- 
nese Centenarians," Science of the Total Environment, Vol. 409, No. 8, 2011, pp. 1385-1390.

http://dx.doi.org/10.1016/j.scitotenv.2011.01.017

[7] N. Violante, O. Senofonte, G. Marsili, P. Meli, M. E. Soggiu and S. Caroli, "Human Hair as a Marker of Pollution by Chemical Elements Emitted by a Thermoeletric Power Plant," Microchemical Journal, Vol. 67, No. 1-3, 2000, pp. 397-405. http://dx.doi.org/10.1016/S0026-265X(00)00099-0

[8] J. Morton, V. A. Carolan and P. H. E. Gardin, "Removal of Exogenously Bound Elements from Human Hair by Various Washing Procedures and Determination by Inductively Coupled Plasma Mass Spectrometry," Analytica Chimica Acta, Vol. 455, No. 1, 2002, pp. 23-34. http://dx.doi.org/10.1016/S0003-2670(01)01578-1

[9] M. Wilhelm, A. Pesch, U. Rostek, J. Begerow, N. Shmitz and H. Ldel, "Concentrations of Lead in Blood, Hair and Saliva of German Children Living in Three Different Areas of Traffic Density," Science of the Total Environment, Vol. 297, No. 1-3, 2002, pp. 109-118. http://dx.doi.org/10.1016/S0048-9697(02)00101-8

[10] R. Pereira, R. Ribeiro and F. Goncalves, "Scalp Hair Analysis as a Tool in Assessing Human Exposure to Heavy Metals (S. Domingos mine, Portugal)," Science of the Total Environment, Vol. 327, No. 1-3, 2004, pp. 81-92. http://dx.doi.org/10.1016/j.scitotenv.2004.01.017

[11] J. L. Rodrigues, B. L. Batista, J. A. Nunes, C. J. S. Passos and F. Barbosa Jr., "Evaluation of the Use of Human Hair for Biomonitoring the Deficiency of Essential and Exposure to Toxic Elements," Science of the Total Environment, Vol. 405, No. 1-3, 2008, pp. 370-376. http://dx.doi.org/10.1016/j.scitotenv.2008.06.002

[12] G. F. Zhao, Z. J. Wang, M. H. Dong, K. F. Ra, J. P. Luo and D. H. Wang, "PBBs, PBDEs, and PCBs Levels in Hair of Residents around E-Waste Disassembly Sites in Zhejiang Province, China, and Their Potential Sources," Science of the Total Environment, Vol. 397, No. 1-3, 2008, pp. 46-57.

http://dx.doi.org/10.1016/j.scitotenv.2008.03.010

[13] T. Wang, J. J. Fu, Y. W. Wang, C. Y. Liao, Y. Q. Tao and G. B. Jiang, "Use of Scalp Hair as Indicator of Human Exposure to Heavy Metals in an Electronic Waste Recycling Area," Environmental Pollution, Vol. 157, No. 8-9, 2009, pp. 2445-2451.

http://dx.doi.org/10.1016/j.envpol.2009.03.010

[14] Y. Kolmogorov, V. Kovaleva and A. Gonchar, "Analysis of Trace Elements in Scalp Hair of Healthy People, Hyperplasia and Breast Cancer Patients with XRF Method," Nuclear Instruments and Methods in Physics Research Section A: Accelerators, Spectrometers, Detectors and Associated Equipment, Vol. 448, No. 1-2, 2000, pp. 457460. http://dx.doi.org/10.1016/S0168-9002(00)00236-9

[15] O. Senofonte, N. Violante and S. Caroli, "Assessment of Reference Values for Elements in Human Hair of Urban Schoolboys," Journal of Trace Elements in Medicine and Biology, Vol. 14, No. 1, 2000, pp. 6-13. http://dx.doi.org/10.1016/S0946-672X(00)80017-6

[16] M. G. Skalnaya and V. A. Demidov, "Hair Trace Element Contents in Women with Obesity and Type 2 Diabetes,"
Journal of Trace Elements in Medicine and Biology, Vol. 21, No. 1, 2007, pp. 59-61. http://dx.doi.org/10.1016/j.jtemb.2007.09.019

[17] G. A. Kandhro, T. G. Kazi, H. I. Afridi, N. Kazi, M. B. Arain, R. A. Sarfraz, et al., "Evaluation of Iron in Serum and Urine and Their Relation with Thyroid Function in Female Goitrous Patients," Biological Trace Element Research, Vol. 125, No. 3, 2008, pp. 203-212. http://dx.doi.org/10.1007/s12011-008-8174-z

[18] G. A. Kandhro, T. G. Kazi, H. I. Afridi, N. Kazi, J. A. Baig, M. B. Arain, et al., "Effect of Zinc Supplementation on the Zinc Level in Serum and Urine and Their Relation to Thyroid Hormone Profile Inmale and Female Goitrous Patients," Clinical Nutrition, Vol. 28, No. 2, 2009, pp. 162-168. http://dx.doi.org/10.1016/j.clnu.2009.01.015

[19] H. I. Afridi, T. G. Kazi, N. Kazi, J. A. Baig, M. K. Jamali, M. B. Arain, et al., "Status of Essential Trace Metals in Biological Samples of Diabetic Mother and Their Neonates," Archives of Gynecology and Obstetrics, Vol. 280, No. 3, 2009, pp. 415-423.

http://dx.doi.org/10.1007/s00404-009-0955-x

[20] G. Dongarrà, M. Lombardo, E. Tamburo, D. Varrica, F. Cibella and G. Cuttitta, "Concentration and Reference Interval of Trace Elements in Human Hair from Students living in Palermo, Sicily (Italy)," Environmental Toxicology and Pharmacology, Vol. 32, No. 1, 2011, pp. 27-34. http://dx.doi.org/10.1016/j.etap.2011.03.003

[21] Kh. Rezaee, M. M. Gharipour, M. R. Abdi and F. Majidi, "Heavy Metals Assessment in the Hair of Street Children by INAA Method, Isfahan," Archives of Gynecology and Obstetrics, Vol. 291, No. 3, 2011, pp. 811-815. http://dx.doi.org/10.1007/s10967-011-1356-8

[22] IAEA, "Activation Analysis of Hair as an Indicator of Contamination of Man of Environ. Trace Poll. Rep. IAEA/ RL/50," Vienna, 1978.

[23] WHO, "Growth Reference Data for 5-19 Years," 2007. http://www.who.int/growthref/en/

[24] A. Movahedi and R. Roosta, "Food Composition Table," 2nd Edition, National Nutrition \& Food Technology Research Institute, Tehran, 2000.

[25] M. Ghaffarpour, A. Hoshiar-Rad and M. Esmaili, "Iranian Food Portion Size Table," 1st Edition, National Nutrition \& Food Technology Research Institute, Tehran, 2001.

[26] Dieary Reference Intakes (DRI), "Recommended Intakes for Individuals, Food and Nutrition Board," Institute of Medicine, National Academies, 2004.

[27] D. Joan, "Cross and Hamilton Smith, Brominein Human Tissue," Forensic Science International, Vol. 11, No. 1, 1978 , pp. $147-153$. http://dx.doi.org/10.1016/0379-0738(78)90109-3

[28] E. Julian, L. Spallholz, M. Boylan, V. Palace, J. Chen, L. Smith, M. M. Rahman and J. D. Robertson, "Arsenic and Selenium in Human Hair, a Comparison of Five Countries with and without Arsenicosis," Biological Trace Element Research, Vol. 106, No. 2, 2005, pp. 133-144. http://dx.doi.org/10.1385/BTER:106:2:133

[29] M. Mosaferi, M. Yunesian, A. R. Mesdaghinia, S. Nasseri, A. H. Mahvi and H. Nadim, "Correlation between Arse- 
nic Concentration in Drinking Water and Human Hair," Iranian Journal of Environmental Health Science \& Engineering, Vol. 2, No. 1, 2005, pp. 13-21.

[30] A. Saada and M. A. Hassanien, "Assessment of Arsenic Level in the Hair of the Nonoccupational Egyptian Population," Pilot Study. Environment International, Vol. 27, No. 6, 2001, pp. 471-478. http://dx.doi.org/10.1016/S0160-4120(01)00102-7

[31] A. G. Gault, H. A. L. Rowland, J. M. Charnock, R. O. Wogelius, I. G. Morilla, S. Vong, M. Leng, S. Samreth, M. L. Sampsond and D. A. Polya, "Arsenic in Hair and Nails of Individuals Exposed to Arsenic-Rich Groundwaters in Kandal Province, Cambodia," Science of the Total Environment, Vol. 393, No. 1, 2008, pp. 168-176.

[32] G. Samanta, R. Sharma, T. Roychowdhury and D. Chakraborti, "Arsenic and Other Elements in Hair, Nails, and Skin-Scales of Arsenic Victims in West Bengal," India Science of the Total Environment, Vol. 326, 2004, pp. 3347.

[33] B. Liu, F. Wu, X. Li, Z. Fu, Q. Deng, C. Mo, J. Zhu, Y. Zhu and H. Liao, "Arsenic, Antimony and Bismuth in Human Hair from Potentially Exposed Individuals in the Vicinity of Antimony Mines in Southwest China," Microchemical Journal, Vol. 97, No. 1, 2011, pp. 20-24. http://dx.doi.org/10.1016/j.microc.2010.07.008

[34] Y. Ming and L. Bing, "Determination of Rare Earth Ele- ments in Human Hair and Wheat Flour Reference Materials by Inductively Coupled Plasma Mass Spectrometry with Dry Ashing and Microwave Digestion," Spectrochimica Acta Part B: Atomic Spectroscopy, Vol. 53, No. 10, 1998, pp. 1447-1454.

http://dx.doi.org/10.1016/S0584-8547(98)00159-1

[35] R. Gonnen, R. Kol, Y. Laichter, P. Marcus, L. Halicz, A. Lorber and Z. Karpas, "Determination of Uranium in $\mathrm{Hu}$ man Hair by Acid Digesion and FIAS-ICPMS," Journal of Radioanalytical and Nuclear Chemistry, Vol. 243, No. 2, 2000, pp. 559-562. http://dx.doi.org/10.1023/A:1016031726512

[36] K. Kehagia, S. Bratakos, M. Kolovou and C. Potiriadis, "Hair Analysis as an Indicator of Exposure to Uranium," Radiation Protection Dosimetery, Vol. 144, No. 1-4, 2011, pp. 423-426. http://dx.doi.org/10.1093/rpd/ncq324

[37] M. A. Drake, "The Nutritional Status and Dietary Adequacy of Single Homeless Women and Their Children in Shelters," Public Health Reports, Vol. 107, No. 3, 1992, pp. 312-318.

[38] R. Grossa, B. Landfriedb and S. Hermanb, "Height and Weight as a Reflection of the Nutritional Situation of School-Aged Children Working and Living in the Streets of Jakarta," Social Science \& Medicine, Vol. 43, No. 4, 1996, pp. 453-458. 